\title{
Commentary on "time-dependent selected reaction monitoring-based GC-MS/MS method for estimation of genotoxic impurities in a new antibacterial agent: alalevonadifloxin mesylate"
}

\author{
D. J. Snodin ${ }^{1 *}$ D, A. Teasdale ${ }^{2}$ and D. P. Elder $^{3}$
}

\begin{abstract}
The references cited in this article to justify the analysis of alkyl mesylates in alalevonadifloxin mesylate (ALA) are considered totally inappropriate since they all present evidence showing that such esters are not formed during the synthesis of a sulfonicacid salt using an alcohol as solvent. Relevant mechanistic and kinetic data, first published over a decade ago, demonstrate that no alkyl-sulfonate impurities are produced when an equimolar amount of methanesulfonic acid is added to the base form of a drug substance dissolved in ethanol (or a similar alcohol solvent), and so confirmatory assay data should not be required.
\end{abstract}

Keywords: Mesylate salt, Alkyl mesylates, Side-reaction

\section{Introduction}

We are writing to raise serious concerns over about the misleading citation of references in the above article by Ahirrao et al., Journal of Analytical Science and Technology volume 11, Article number: 22 (2020) (Ahirrao et al. 2020).

"Synthesis of ALA involves the use of methanol, ethanol, and isopropanol as solvents at various staged of synthesis and during purification. Though possibility of reaction between the methane sulfonic acid and the alcohols is ruled out in the formation of AMs (Teasdale et al. 2010; Snodin and Teasdale 2015; Snodin 2019), it is regulatory mandate to estimate levels of AMs in the drug substance."

This comment refers to the article available at https://doi.org/10.1186/ s40543-020-00214-w.

* Correspondence: snodind@xiphora.com

${ }^{1}$ Xiphora Biopharma Consulting, Bristol, UK

Full list of author information is available at the end of the article

\section{Commentary}

We wish to point out that none of the articles supports the notion that undesired reactions between methanesulfonic acid (MSA) and alcohols during the synthesis of a mesylate-salt drug substance result in the formation of alkyl-mesylate impurities. All three publications strongly contradict the false belief that alkyl mesylates can be formed by a side-reaction during sulfonic-acid-salt synthesis using an alcohol solvent. When an equimolar amount of MSA is added to the base form of an API a proton-transfer reaction from acid to base occurs. These reactions are diffusion-controlled and so base protonation is essentially instantaneous leading to complete neutralization of added sulfonic acid. There is therefore no scope for alcohol protonation which is a necessary prerequisite for an esterforming side-reaction; protonation of the alcohol requires very strongly acidic conditions, i.e., $\mathrm{pH}<<1$. Moreover, sulfonic-acid salts can be recrystallized using ethanol (or a similar alcohol) as a solvent without any production of ethyl-sulfonate impurities. To generate alkyl sulfonates at neutral $\mathrm{pH}$ in such a system, the mechanistically impossible 
nucleophilic displacement of hydroxide ion by sulfonate anion would need to occur.

It is also noteworthy that Ahirrao et al., in common with many others developing assay methods for alkyl sulfonates, provide no assay data on alkyl mesylates in commercial samples of ALA drug substance or drug product. We believe that such information is necessary to support or refute the hypotheses employed to justify the development of the GC-MS/MS assay. There is one recent exception to this normal pattern (Jin et al. 2019); these researchers actually applied their assay method for 15 sulfonate esters to commercial samples of three drug products: phentolamine mesylate, amlodipine besylate, and tosufloxacin tosylate. None of esters was detected in any of the drug products under investigation.

\section{Conclusions}

We consider that Ahirrao et al. have cited our articles in an extremely misleading fashion wrongly implying that these publications provide a justification for the development of highly sensitive assays for alkylmesylate impurities. We recommend revision of this article by means of an author correction in order to provide a truly evidenced-based understanding of the risk of alkyl-mesylate contamination of mesylate-salt drug substances.

\section{Acknowledgements}

Not applicable

\section{Authors' contributions}

Initial draft by DJS; review and comments by AT and DPE. The authors read and approved the final manuscript.

\section{Funding}

Not applicable: no external funding was provided to support the preparation of this short article. We, the authors, declare that we have no financial or other conflicts of interest and that no external funding was provided to support the preparation of this short article.

\section{Availability of data and materials}

See cited references.

\section{Competing interests}

Not applicable

\section{Author details}

${ }^{1}$ Xiphora Biopharma Consulting, Bristol, UK. ${ }^{2}$ AstraZeneca, Macclesfield, UK.

${ }^{3}$ David P Elder Consultancy, Hertford, UK.

Received: 9 August 2020 Accepted: 23 October 2020

Published online: 10 November 2020

\section{References}

Ahirrao VK, et al. Time-dependent selected reaction monitoring-based GC-MS/MS method for estimation of genotoxic impurities in new antibacterial agent: alalevonadifloxacin mesylate. J Anal Sci Technol. 2020;11:1-9. https://doi.org/ 10.1186/s40543-020-00214-w.

Jin B, et al. Simultaneous determination of 15 sulfonate ester impurities in phentolamine mesylate, amlodipine besylate, and tosufloxacin tosylate by LC-APCl-MS/MS. J Anal Methods Chem. 2019;2019:1-7. https://doi.org/10. $1155 / 2019 / 4059765$.
Snodin D, Teasdale A. Mutagenic alkyl-sulfonate impurities in sulfonic acid salts: reviewing the evidence and challenging regulatory perceptions. Org Process Res Dev. 2015;19:1465-85. https://doi.org/10.1021/op500397h.

Snodin DJ. Elusive impurities_evidence versus hypothesis. Technical and regulatory update on alkyl sulfonates in sulfonic acid salts. Org Process Res Dev. 2019;23:695-710. https://doi.org/10.1021/acs.oprd.8b00397.

Teasdale A, et al. A detailed study of sulfonate ester formation and solvolysis reaction rates and application toward establishing sulfonate ester control in pharmaceutical manufacturing processes. Org Process Res Dev. 2010;14:999_ 1007. https://doi.org/10.1021/op900301n.

\section{Publisher's Note}

Springer Nature remains neutral with regard to jurisdictional claims in published maps and institutional affiliations.

\section{Submit your manuscript to a SpringerOpen ${ }^{\circ}$ journal and benefit from:}

- Convenient online submission

- Rigorous peer review

- Open access: articles freely available online

- High visibility within the field

- Retaining the copyright to your article

Submit your next manuscript at $\boldsymbol{\nabla}$ springeropen.com 